\title{
The effect of copper on the mineralization of bones of mice fed on a meat diet
}

\author{
BY K. GUGGENHEIM, E. TAL AND U. ZOR \\ Laboratory of Nutrition, Hebrew University-Hadassah Medical School, \\ ferusalem, Israel
}

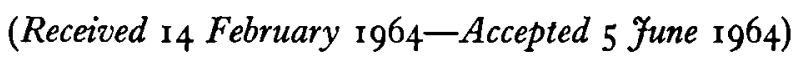

It has been reported that the bone ash of young mice kept for 6 weeks on a diet composed entirely of muscle meat was markedly reduced; osteoporosis could be demonstrated radiologically as well as histologically (Ilan, Schwartz \& Guggenheim, 1962; Ulmansky, r964). The disorder was completely prevented by the addition of calcium carbonate or, to a lesser degree, by replacement of one-quarter of the meat by beef liver. Since liver contains more copper than muscle, the meat diet was supplemented with $20 \mathrm{mg} \mathrm{Cu} / \mathrm{kg}$. This supplement increased considerably the proportion of bone ash. It is noteworthy that $\mathrm{Cu}$ exerted this effect on the mineralization of bone when added to a basal diet, i.e. meat, that is poor in calcium and rich in phosphorus. It was thought that this effect of $\mathrm{Cu}$ deserved further investigation. Mice were therefore maintained on a meat diet to which $\mathrm{Cu}$ had been added. After various times their femurs were analysed for bone ash, calcium, phosphorus and manganese, and the incorporation of radioactive $\mathrm{Ca}$ was measured.

\section{METHODS}

The study involved 432 male Swiss mice. They came from a stock maintained, without inbreeding, at the Hebrew University for over 15 years. They were 3 weeks old and weighed ro-r $3 \mathrm{~g}$. They were divided into six groups. The diets consisted of raw lean beef muscle, which was offered either unsupplemented (first group) or supplemented with $\mathrm{Cu}$ or $\mathrm{Ca}$. Thus, the diets of groups 2-5 were supplemented with $2.5,5^{\circ}$, 10.0 and $20.0 \mathrm{mg} \mathrm{Cu}$ (as $\mathrm{CuSO}_{4}$ ) $/ \mathrm{kg}$ and that of group 6 with $3^{.6} \mathrm{~g} \mathrm{Ca}$ (as $\left.\mathrm{CaCO}_{3}\right) / \mathrm{kg}$. A similar supplement $(3 \cdot 3 \mathrm{~g} / \mathrm{kg})$ of $\mathrm{Ca}$ as $\mathrm{CaCO}_{3}$ had previously been found to induce normal mineralization of bones in mice fed on this diet (Ilan et al. I 962; Ulmansky, r 964). The Ca content of the meat was examined in twelve samples and found to be 95 (standard error: $5{ }^{\circ} 9$ ) $\mathrm{mg} / \mathrm{kg}$.

Twenty-four mice of each group, i.e. one-third, were killed after 2 weeks and twenty-four mice each after 4 and 6 weeks. The femurs were cleaned of adherent tissue and weighed. They were then broken, extracted for $6 \mathrm{~h}$ with alcohol in a Soxhlet apparatus, dried to constant weight and ashed at $600^{\circ}$. In the ash, $\mathrm{Ca}$ (Baron \& Bell, 1959), P (Fiske \& Subbarow, I925) and Mn (Gates \& Ellis, 1947) were determined. $\mathbf{P}$ and $\mathrm{Mn}$ were determined in the bones of eighteen mice only from each group. Measured portions of the ash of three pairs of femurs were pooled. The figures 
shown in the tables therefore indicate means of six samples, each comprising three pairs of femurs.

In six animals of each group the uptake of radioactive $\mathrm{Ca}$ by bone was studied. These six mice had received at the end of their periods of observation a subcutaneous injection of ${ }^{45} \mathrm{CaCl}_{2}$. Each mouse was injected with $0 . \mathrm{I} \mu \mathrm{c}$ in $1.0 \mathrm{mg} \mathrm{Ca}$ per $10 \mathrm{~g}$ body-weight. On the next day the animals were killed, and their femurs were ashed at $600^{\circ}$. The ash was dissolved in $\mathrm{I} \mathrm{N}-\mathrm{HCl}$, and a measured portion was taken for determination of radioactivity. The results are expressed as $\mu \mathrm{g}$ of dose administered per $\mathrm{g}$ of fresh bone or per $100 \mathrm{mg}$ of bone $\mathrm{Ca}$.

\section{RESULTS}

The results obtained after observation periods of 2,4 and 6 weeks are presented in Tables I-3.

Even after 2 weeks the effects of supplementing the meat with $\mathrm{Cu}$ were discernible. Weight increase was raised; with $20 \mathrm{mg} \mathrm{Cu}$ added $/ \mathrm{kg}$ meat it almost equalled that of mice maintained on the diet enriched with $\mathrm{Ca}$. Bone weight likewise was higher when the meat diet had been supplemented with $\mathrm{Cu}$. The mean weight of both femurs of mice that had subsisted on the unsupplemented diet was $68 \mathrm{mg}$. It increased to 84-97 $\mathrm{mg}$ when $\mathrm{Cu}$ had been added to the diet and to $98 \mathrm{mg}$ on the meat diet supplemented with $\mathrm{Ca}$. Figures for ash, $\mathrm{Ca}$ and $\mathrm{P}$ generally increased with increasing amounts of $\mathrm{Cu}$ added. With the highest $\mathrm{Cu}$ supplement, however, ash content slightly decreased, and the percentage of $\mathrm{Ca}$ and $\mathrm{P}$ in fresh bone likewise declined. The percentages of $\mathrm{Ca}$ and $\mathrm{P}$ in the bone ash of mice whose diet had been supplemented with $\mathrm{Cu}$ were similar to or even slightly higher than those of mice fed on the diet enriched with $\mathrm{Ca}$. Fortification of meat with $\mathrm{Cu}$ resulted in a lower incorporation of ${ }^{45} \mathrm{Ca}$ in bone and in bone $\mathrm{Ca}$. Mice that had received the highest $\mathrm{Cu}$ supplement did not incorporate significantly more $\mathrm{Ca}$ into bone than did mice given the diet enriched with $\mathrm{Ca}$. Addition of $\mathrm{Cu}$ to meat increased not only $\mathrm{Ca}$ and $\mathrm{P}$ in bones, but also $\mathrm{Mn}$. Ash and bone of mice on the Cu-supplemented diet contained significantly more $\mathrm{Mn}$ than did those of control mice. Moreover, addition of $\mathrm{Cu}$ caused a much greater increase of $\mathrm{Mn}$, both in ash and in fresh bone, than of $\mathrm{Ca}$ and $\mathrm{P}$.

The effects of adding small amounts of $\mathrm{Cu}$ to meat were more evident when the observation period was prolonged to 4 or 6 weeks (Tables 2 and 3 ). After 4 weeks, the weight increase of the mice was significantly raised by the addition of only $2.5 \mathrm{mg} \mathrm{Cu} / \mathrm{kg}$ meat. Moreover, supplementation of meat with $\mathrm{Cu}$ induced a considerable weight increase between the 2 nd and the $4^{\text {th }}$ week and between the $4^{\text {th }}$ and the 6th week; the growth performance of the mice receiving the highest $\mathrm{Cu}$ supplement resembled that of mice given the $\mathrm{Ca}$-enriched diet. On the other hand, the mice kept on the unsupplemented diet almost ceased growing after the and week.

The increases in $\mathrm{Ca}$ and $\mathrm{P}$ contents of bone ash resulting from supplementation with $\mathrm{Cu}$ did not greatly differ after 6 weeks from those observed after 2 and 4 weeks. However, the concentrations of these minerals in fresh bone increased markedly with prolongation of the observation period. These increases were accompanied by lowered incorporation of ${ }^{45} \mathrm{Ca}$ in fresh bone and in bone $\mathrm{Ca}$. 
Vol. I8

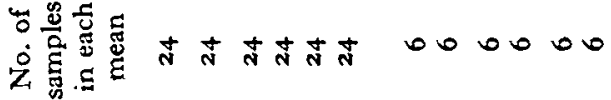

ริ

N

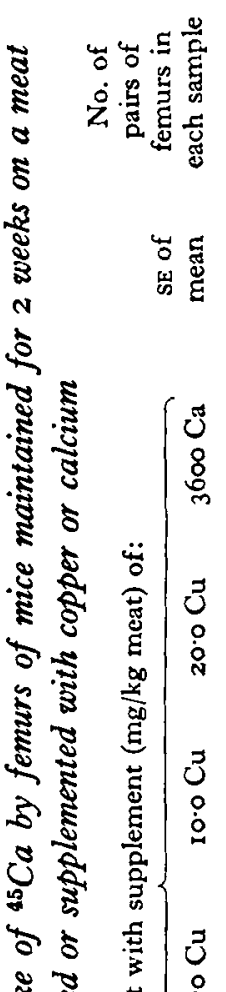

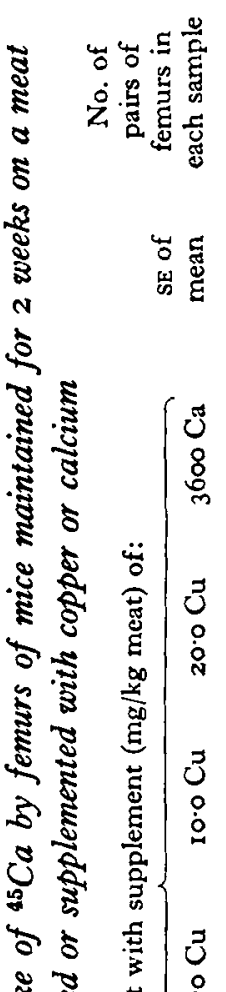

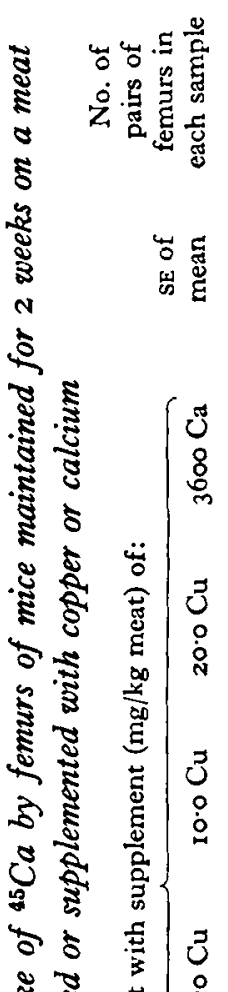

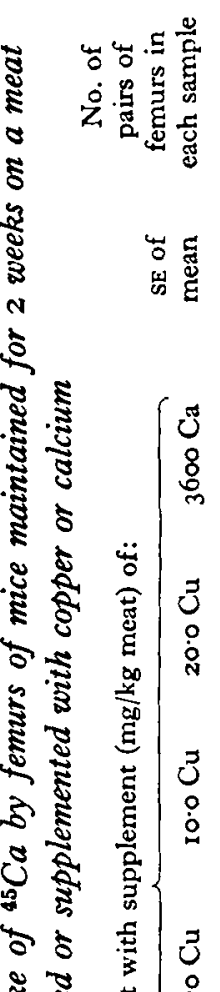

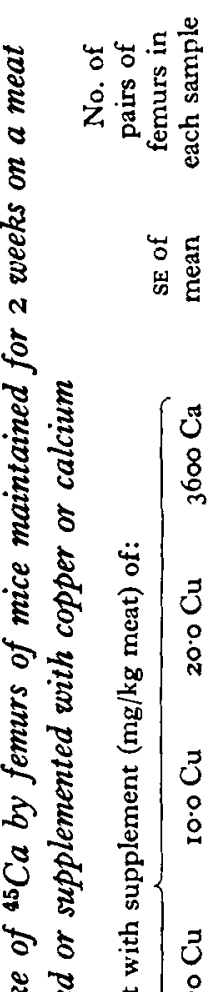

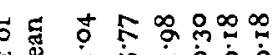

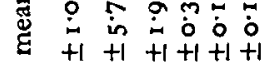

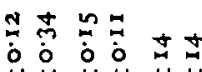
$+1+1+1+1+1+1$

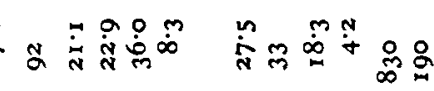

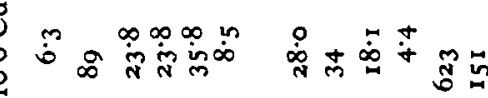

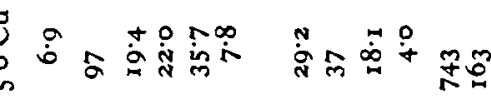



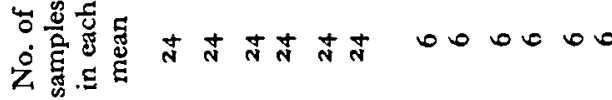

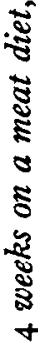

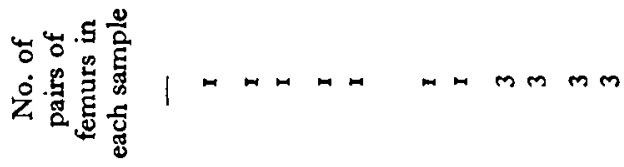

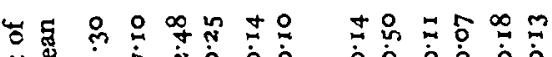

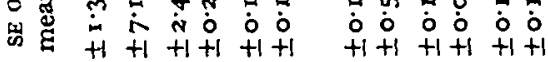

8 ह

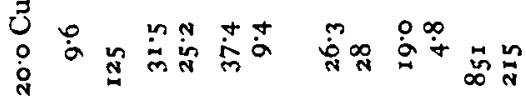

Uี

8

皮

है

:

.5

Uె口

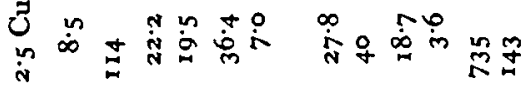

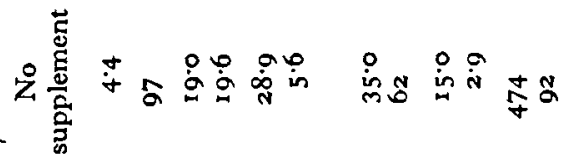

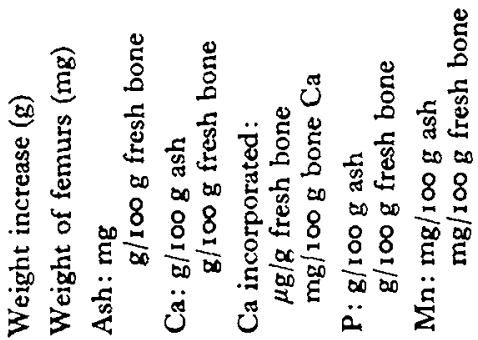




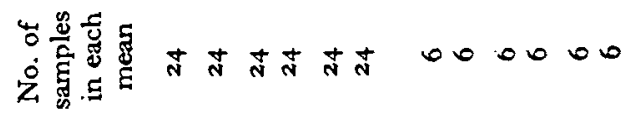

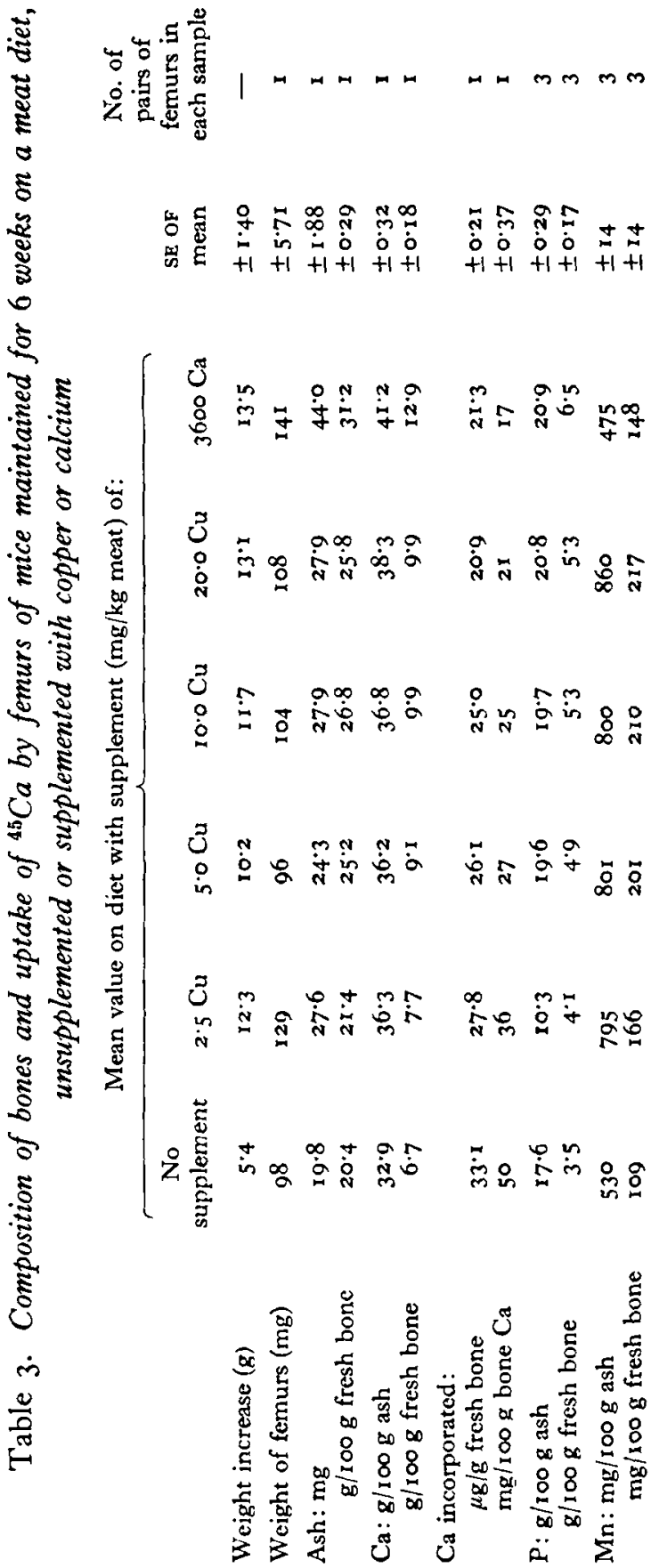


Mn content of ash and fresh bone tended to increase, particularly after 6 weeks.

It therefore appears that $\mathrm{Cu}$ added to meat improves mineralization of bone of mice fed upon meat.

\section{DISCUSSION}

Our findings indicate that mice maintained on a diet consisting of beef muscle develop a severe bone disorder; bone ash and concentrations of $\mathrm{Ca}$ and $\mathrm{P}$ in both fresh bone and bone ash decrease, and the incorporation of ${ }^{45} \mathrm{Ca}$ in bones decreases. This disorder is completely prevented by the addition of $\mathrm{Ca}$ to the meat. Bone ash and the concentrations of $\mathrm{Ca}$ and $\mathrm{P}$ in bones and ash of mice subsisting on a meat diet enriched with $\mathrm{Ca}$ resemble those found in mice raised on a presumably normal stock diet (Guggenheim \& Tal, unpublished).

Adding 2.5-20.0 $\mathrm{mg} \mathrm{Cu} / \mathrm{kg}$ meat considerably improved growth and mineralization of bones. It increased not only the amount of bone ash and the contents of $\mathrm{Ca}$ and $\mathrm{P}$ in fresh bones and in ash, but also that of another mineral with an affinity for bone tissue and so tending to accumulate in bone, i.e. Mn (Underwood, 1962, p. 189). The effect of $\mathrm{Cu}$ was generally greater when the quantity added to meat was increased and when the observation period was prolonged. The amounts of ash, $\mathrm{Ca}$ and $\mathrm{P}$ in bones as well as the uptake of ${ }^{45} \mathrm{Ca}$ by bones of animals receiving the highest $\mathrm{Cu}$ supplement resembled more closely those of mice kept on meat supplemented with Ca than those of mice fed on unsupplemented meat. The improved mineralization of bones of mice maintained on meat enriched with $\mathrm{Cu}$ is probably not the result of the weight gain brought about by the supplement. Rats kept on the meat diet for 9 weeks do not increase their weight more when $20 \mathrm{mg} \mathrm{Cu} / \mathrm{kg}$ of meat are added, though this supplement leads to a significant increase in bone $\mathrm{Ca}$ and $\mathrm{P}$ and a marked decrease in uptake of injected ${ }^{45} \mathrm{Ca}$ (Tal \& Guggenheim, unpublished).

The deleterious effect exerted by a meat diet on the skeleton of kittens (Scott, Greaves \& Scott, 196I) and of rats (Moore \& Sharman, 1960) has been reported. Growth of rats ceased after a few weeks, and the bones were undersized, had thin walls and a low ash content and were often fractured. The disorder could be prevented by adding adequate amounts of $\mathrm{Ca}$ to meat (Moore, Sharman, Constable, Symonds, Martin \& Collinson, I 962). Our results indicate that not only $\mathrm{Ca}$ is involved. Meat is a poor source of $\mathrm{Cu}$, containing only $\mathrm{I} \cdot 3 \mathrm{mg} / \mathrm{kg}$ (Guggenheim, Ilan, Fostick \& Tal, 1963). Rats fed upon meat are, therefore, liable to develop $\mathrm{Cu}$ deficiency (Moore, I962).

Bone defects resulting in spontaneous fractures have been described in sheep and cattle grazing on $\mathrm{Cu}$-deficient pastures (Underwood, I962, p. 75). Histological studies of dogs made deficient in Cu (Baxter \& Van Wyk, 1953; Baxter, Van Wyk \& Follis, 1953) indicated that there was an excessive resorption of bone, with decreased deposition of bone matrix. The ash content remained normal, however, probably because the diet supplied sufficient $\mathrm{Ca}$.

Muscle meat is not only poor in $\mathrm{Ca}$ and $\mathrm{Cu}$ but is rich in $\mathrm{Zn}$ (Guggenheim, ${ }_{1964}$ ). Intestinal absorption of $\mathrm{Zn}$ is lowered by $\mathrm{Ca}$ (Guggenheim, 1964), and its toxic effects are counteracted by $\mathrm{Cu}$ (Underwood, I962, p. I $8 \mathrm{I}$ ). Thus, the anaemia developing in 
mice kept on a meat diet can be prevented by adding $\mathrm{Cu}$ or $\mathrm{Ca}$ to the meat. Moreover, mice appear to be more susceptible to the toxic action of $\mathrm{Zn}$ than are rats (Guggenheim, 1964). Dietary excess of $\mathrm{Zn}$ has been shown to affect weight gain in young rats and to decrease bone $\mathrm{Ca}$ and $\mathrm{P}$ (Stewart \& Magee, r 964). 'The deleterious effect of the meat diet on bones of mice may, therefore, partly result from the excess of $\mathrm{Zn}$ present in meat, which can be counteracted by $\mathrm{Ca}$ or $\mathrm{Cu}$. Recently, Moore, Constable, Day, Impey \& Symonds (1964) reported that the ash content of femurs of young rats fed for 7 weeks upon meat is low. Addition of $5 \mathrm{mg} \mathrm{Cu} / \mathrm{kg}$ meat increased it only slightly. In the experiments mentioned above (Tal \& Guggenheim, unpublished) supplementation of meat with $20 \mathrm{mg} \mathrm{Cu} / \mathrm{kg}$ did not affect bone ash of young rats after a 4 -week period, but had a small though distinct effect after 9 weeks. The different responses of rats and mice to a meat diet may reside in their different susceptibility to the toxic action of $\mathrm{Zn}$.

The meat diet is also characterized by a high content of protein. The interaction of protein and $\mathrm{Ca}$ on growth and composition of bones has recently been studied in young rats (El-Maraghi \& Stewart, I963). Bones of rats kept on a high-protein, low-Ca diet had a lower ash content with a lower radiographic density than bones of rats on a low-protein, low-Ca diet. El-Maraghi \& Stewart ( $\mathrm{Ig}\left({ }^{1} 3\right)$ conclude that 'an osteoporosis-like condition may therefore be produced in growing animals when protein and $\mathrm{Ca}$ intakes are unbalanced'. Thus, demineralization of bones of mice subsisting on the unsupplemented meat diet may be aggravated by the gross imbalance of protein and $\mathrm{Ca}$.

\section{SUMMARY}

I. Young mice were fed on muscle meat, which was either unsupplemented or supplemented with $2.5,5.0,10.0$ or $20.0 \mathrm{mg}$ copper or with $3.6 \mathrm{~g}$ calcium per $\mathrm{kg}$. After 2, 4 and 6 weeks the composition of the femurs and their uptake of ${ }^{45} \mathrm{Ca}$ were investigated.

2. Mice maintained on the unsupplemented meat diet ceased growing after the 2nd week. The amounts of ash, $\mathrm{Ca}$ and $\mathrm{P}$ in their bones were low, and incorporation of ${ }^{45} \mathrm{Ca}$ was high. Mice given the $\mathrm{Ca}$-enriched diet had much more ash, $\mathrm{Ca}$ and $\mathrm{P}$ in their bones and a lower uptake of ${ }^{45} \mathrm{Ca}$. The differences ircreased with prolongation of the experimental period.

3. Mice kept on the diet supplemented with $\mathrm{Cu}$ increased in weight during the whole experimental period; their femurs were heavier than those of the mice consuming the unsupplemented meat and contained more ash, $\mathrm{Ca}, \mathrm{P}$ and $\mathrm{Mn}$. Incorporation of ${ }^{45} \mathrm{Ca}$ was lower, suggesting improved mineralization. The effect of $\mathrm{Cu}$ generally increased on increasing the quantity added to meat and on prolonging the experimental period.

4. It is concluded that $\mathrm{Cu}$ improves mineralization of bones of mice when they subsist on a meat diet.

This study was supported by research grant A-4358 from the National Institutes of Health, Bethesda, Maryland, USA. 


\section{REFERENCES}

Baron, D. N. \& Bell, J. L. (1959). F. clin. Path. 12, 143.

Baxter, J. H. \& Van Wyk, J. J. (1953). Bull. Fohns Hopkins Hosp. 93, 1.

Baxter, J. H., Van Wyk, J. J. \& Follis, R. H. (1953). Bull. Fohns Hopkins Hosp. 93, 25.

El-Maraghi, N. R. H. \& Stewart, R. J. C. (1963). Proc. Nutr. Soc. 22, xxx.

Fiske, C. H. \& Subbarow, Y. (1925). F. biol. Chem. 66, 375.

Gates, E. M. \& Ellis, G. H. (1947). F. biol. Chem. 168, 537.

Guggenheim, K. (1964). Blood, 20, 786.

Guggenheim, K., Ilan, J., Fostick, M. \& Tal, E. (1963). F. Nutr. 79, 245.

Ilan, J., Schwartz, A. \& Guggenheim, K. (rg62). Metabolism, II, 535.

Moore, 'Г. (1962). Brit. med. भ. i, 689.

Moore, T., Constable, B. J., Day, K. C., Impey, S. G. \& Symonds, K. R. (I964). Brit. F. Nutr. 18, 135 .

Moore, T. \& Sharman, I. M. (1960). Brit. med. F. ii, 1704.

Moore, T., Sharman, I. M., Constable, B. J., Symonds, K. R., Martin, P. E. N. \& Collinson, E. (1962). 7. Nutr. 77, 415 .

Scott, P. P., Greaves, J. P. \& Scott, M. G. (1961). Brit. F. Nutr. 15, 35.

Stewart, A. K. \& Magee, A. C. (1964). F. Nutr. 82, 287.

Ulmansky, M. (1964). Amer. F. Path. 44, 85.

Underwood, E. J. (1962). Trace Elements in Human and Animal Nutrition, and ed. New York: Academic Press Inc. 